\title{
Molluscs associated with the macroalgae of the genus Gracilaria (Rhodophyta): importance of algal fronds as microhabitat in a hypersaline mangrove in Northeastern Brazil
}

\author{
Queiroz, RNM. ${ }^{a}$ and Dias, TLP. ${ }^{a *}$ \\ áLaboratório de Biologia Marinha, Departamento de Biologia, Universidade Estadual da Paraíba - UEPB, Campus I, \\ Rua das Baraúnas, 351, Bairro Universitário, CEP 58429-500, Campina Grande, PB, Brazil \\ *e-mail: thelmalpdias@gmail.com
}

Received: September 18, 2012 - Accepted: August 26, 2013 - Distributed: November 30, 2014

(With 5 figures)

\begin{abstract}
The fronds of marine macroalgae play an important role in coastal ecosystems because the algae banks are utilized as a microhabitat by different taxa, including molluses, one of the most abundant and diverse animals of marine ecosystems. In this study, we characterized the malacofauna associated with the macroalgae Gracilaria domingensis (Kützing) Sonder ex Dickie 1874 and Gracilaria cuneata Areschoug 1854 of a hypersaline mangrove on the northern coast of the state of Rio Grande do Norte, Northeastern Brazil. The first alga dominates in the rainy season and it is substituted by second one in the dry period. A total of 1,490 molluscs were surveyed, representing 56 species in 29 families: 1,081 were associated with $G$. domingensis and 409 with $G$. cuneata, the latter showing the greater diversity $\left(\mathrm{H}^{\prime}=1.25\right)$. Columbellidae, Neritidae, Pyramidellidae and Cerithiidae were among the most representative families in the number of species and individuals. The micromolluscs were dominant in the algal microhabitat, constituting $74.63 \%$ of the malacofauna recorded. The columbellid Parvanachis obesa (C. B. Adams, 1845) was the dominant species followed by the neritid Neritina virginea (Linnaeus, 1758) in both algae. In spite of the annual alternated succession of the algae species, at least 15 mollusc species are common for these algae. Furthermore, juveniles of $P$. obesa were recorded in both seasons, indicating a continuous reproduction. Possible reasons for difference in abundance, diversity and dominance of molluscs living on these algae are discussed. Both species of substrate-algae represent an important microhabitat for refuge, feeding and the reproduction of small-sized mollusc species during rainy and dry seasons.
\end{abstract}

Keywords: mollusc diversity, inventory, semiarid littoral, Ponta do Tubarão, Parvanachis obesa.

\section{Moluscos associados a macroalgas do gênero Gracilaria (Rhodophyta): importância das frondes algais como microhabitat em um manguezal hipersalino no Nordeste do Brasil}

\begin{abstract}
Resumo
As frondes de macroalgas marinhas exercem um importante papel nos ecossistemas costeiros, tendo em vista que os bancos de algas são utilizados como microhabitat por diferentes táxons, incluindo os moluscos, que estão entre os mais abundantes e diversos animais dos ecossistemas marinhos. Neste estudo, caracterizou-se a malacofauna associada às macroalgas Gracilaria domingensis (Kützing) Sonder ex Dickie 1874 e Gracilaria cuneata Areschoug 1854 de um manguezal hipersalino da costa norte do estado do Rio Grande do Norte, Nordeste do Brasil. A primeira alga domina no período chuvoso e é substituída pela segunda no período seco. Foram inventariados 1.490 moluscos, representando 56 espécies em 29 famílias: 1.081 estavam associados a G. domingensis e 409 a G. cuneata, esta última apresentando maior diversidade $\left(H^{\prime}=1,25\right)$. Columbellidae, Neritidae, Pyramidellidae e Cerithiidae estiveram entre as famílias mais representativas em número de espécies e indivíduos. Os micromoluscos foram dominantes no microhabitat algal, constituindo 74,63\% da malacofauna registrada. O columbelídeo Parvanachis obesa (C. B. Adams, 1845) foi a espécie dominante, seguida pelo neritídeo Neritina virginea (Linnaeus, 1758) em ambas as algas. Apesar da sucessão alternada anual das espécies de algas, pelo menos 15 espécies de moluscos são comuns a estas algas. Além disso, os jovens de $P$. obesa foram registrados em ambas as estações, indicando uma reprodução contínua. São discutidas possíveis razões para a diferença na abundância, diversidade e dominância dos moluscos habitantes destas algas. Ambas as espécies de alga-substrato representam um importante microhabitat para refúgio, alimentação e reprodução para pequenas espécies de moluscos durante as estações chuvosa e seca.
\end{abstract}

Palavras-chave: diversidade de moluscos, inventário, litoral semiárido, Ponta do Tubarão, Parvanachis obesa. 


\section{Introduction}

The fronds of marine macroalgae play an important role in coastal ecosystems (Edgar, 1983a; Hacker and Steneck, 1990; Chemello and Milazzo, 2002). It is known that, in addition to providing biomass and energy and occupying the base of the food chain, they also offer shelter and protection for various organisms. These algae and the banks that they form reduce the action of water streams, and their fronds confer greater stability to the sediment, guaranteeing more protection against erosion (Chemello and Milazzo, 2002). The macroalgae interact in modelling hydrodynamics, the availability of food and habitat complexity, which are important regulatory agents for phytal communities (Kershner and Lodge, 1990; Hauser et al., 2006).

According to Edgar (1983b), many animals live in association with marine macroalgae or have some type of relationship with them, and can even be utilized as a place for spawning. Among the fauna found in these microhabitats, it is important to highlight the groups of animals that are consumed by humans and that have commercial importance, such as molluses and fishes. However, other diversified taxa, such as crustaceans, polychaetes, echinoderms and cnidarians, also utilize the fronds of macroalgae as a permanent or even a temporary habitat (Azevedo, 1992).

Among the different taxa that utilize banks of algae as a microhabitat, the molluscs are among the most abundant and diverse (Azevedo, 1992). Studies revealed that the molluscan assemblage living in association with algal fronds can be very diversified and varies according to the algal architecture (Chemello and Milazzo, 2002). According to these authors, the morphological complexity of the algae that constitutes the characteristic attribute of the habitat can influence the availability of food because they can harbour a great variety of food resources and provide shelter against predators. However, it is important to note that the importance of these microhabitats for particular taxa is little recognized, because the species that live in them are generally small.

Thus, understanding the importance of macroalgae as a microhabitat for small-sized species, which generally occupy the lowest trophic levels, can contribute to a better knowledge of the dynamics of these ecosystems and of the species that they harbour.

The aim of this study was to inventory the molluscan assemblage associated with macroalgae of the genus Gracilaria, in the hypersaline mangrove of the Tubarão River, state of Rio Grande do Norte, Northeastern Brazil. Furthermore, it was analyzed and discussed the importance of these macroalgae as a microhabitat for molluscs in a hypersaline environment, information that was provided by the study of the population structure of the micromollusc Parvanachis obesa (C. B. Adams, 1845), the most abundant species associated with these algae.

\section{Material and Methods}

\subsection{Study site}

The study was conducted in the hypersaline mangrove of Tubarão River (5'04'37'S and 36 27'24'W), located in the district of Diogo Lopes, municipality of Macau, northern coast of the state of Rio Grande do Norte, Northeastern Brazil (Figure 1a-c).

Tubarão River is within the ambit of a sustainable use conservation area, the Ponta do Tubarão Sustainable Development Reserve (PTSDR). The mangrove, with human populations established along its margins, is situated in an area with a semi-arid climate, high evaporation rates and little rainfall (annual mean of $537.5 \mathrm{~mm}$ ) (IDEMA, 2004). This mangrove is situated on high ground and is characterized as an estuarine tidal flat (IDEMA, 2004). The area is created by a long arm of sea that penetrates the continent by $10 \mathrm{~km}$. It is not fed by a freshwater spring, and only receives freshwater from subjacent groundwater and the scarce rains that occur mainly from March to May. These tidal flats have a variable salinity, which is high in relation to positive estuaries, oscillating from 37 to 50 (Dias, 2006).

The PTSDR mangrove is strongly influenced by the dynamics of the tides. During low tides, sandbanks emerge along the mangrove, resulting in the accumulation of sediment at some points. The channels of the river are narrow and have a low volume of water, and small tide pools are observed at some points (Dias et al., 2007).

\subsection{Field and laboratory procedures}

Two samplings were conducted in 2011, one in April and the other in September, within the local rainy and dry periods, respectively. Sample collection was carried out by free diving during low tide. In the dry season month, five algal fronds of Gracilaria domingensis (Kützing) Sonder ex Dickie 1874 were collected, which were found in turbid waters with a high salinity of 40 , in a sector located approximately $8 \mathrm{~km}$ from the mouth of the river. The depth at the sampling site was $0.8 \mathrm{~m}$. In the rainy month, five algal fronds of G. cuneata Areschoug 1854 were obtained in turbid water with a high salinity of 41 , totalling ten fronds that were used for analysis in this study. The sector of the second sampling was situated approximately $7.5 \mathrm{~km}$ from the mouth of the river, where the depth was $1 \mathrm{~m}$ (Figure 1b). It was not possible to sample the fronds of the second collection from the same site as the first because the algae did not occur in exactly the same location all the year round: $G$. domingensis occurs mainly in the dry season and is substituted by $G$. cuneata in the rainy period (Lucena, 2012). However, although the fronds have been collected from different collection points, both species were found in locations with similar abiotic characteristics such as bottom type, depth and salinity. Both algae species were also collected at intertidal zone, during low tides.

During collection, the algal fronds were wrapped in plastic bags to prevent animals from escaping and then, 

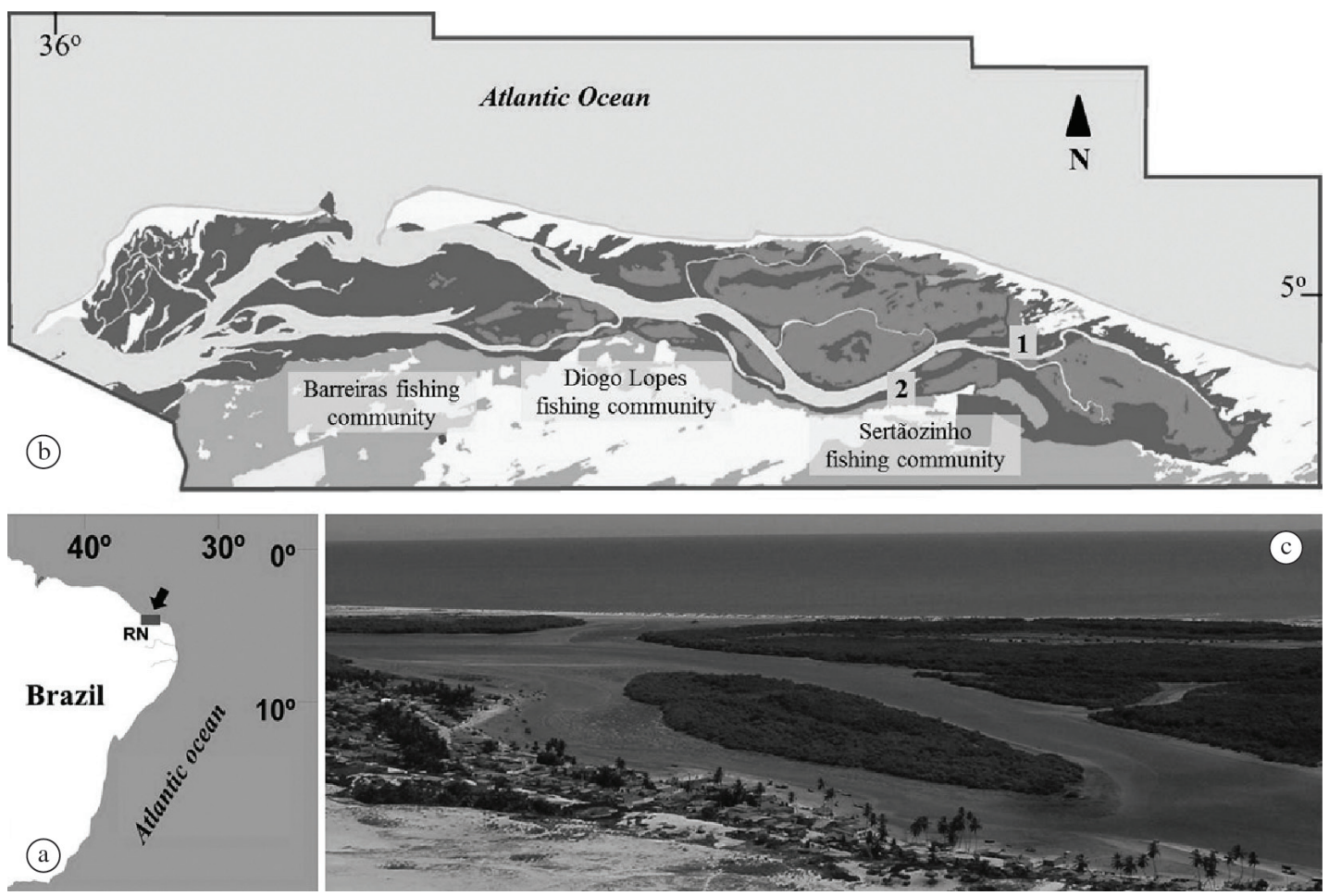

Figure 1. (a) Location of the Rio Grande do Norte State in the Brazilian coast. (b) Map of the studied area with indication of the collection sites along the Tubarão River: 1. collection site of Gracilaria domingensis carried out in the dry month and 2. collection site of Gracilaria cuneata carried out in the rainy month. (c) Partial view of the estuarine system of Ponta do Tubarão Sustainable Development Reserve, Rio Grande do Norte State, NE Brazil. Photograph by Getúlio Moura.

their base was manually removed from the soft substrate or from the holdfast, usually an empty shell. After collection, each algal frond was individually placed in plastic bags containing water from the collection site. Next, the samples were placed in containers with aeration, in order to sort the associated malacofauna. Each sample was washed with the help of a $0.5-\mathrm{mm}$ mesh sieve to remove sediment and to prevent the loss of small molluscs. These were anaesthetized in natural water containing menthol, fixed and preserved in $70 \%$ alcohol for later identification. The fronds of the collected algae were preserved in $10 \%$ formalin for visual characterization of the specimens, which was performed in the Marine Biology Laboratory of State University of Paraíba. The fronds were also examined for the presence of epibionts and algal epiphytes.

The associated malacofauna was identified under a stereomicroscope with the help of specific literature (e.g. Hartmann, 2006; Mikkelsen and Bieler, 2008; Rios, 2009; Thomé et al., 2010; Tunnell Junior et al., 2010). Parvanachis obesa (family Columbellidae), the most abundant mollusc species found in the two algae, was studied in detail to determine the size structure of its population, as well as its coloration pattern. The total length of the shell (from the protoconch to the siphonal notch) was measured under the stereomicroscope with a graduated rule of $0.01 \mathrm{~mm}$ precision.

\subsection{Visual characterization of the studied macroalgae}

The two species of macroalgae were visually characterized to obtain information about the microhabitat that they provide. This was undertaken by examining the appearance of the frond, its general shape (branched or not) and the shape of the branches, as well as how they establish themselves in the environment (erect, prostrate). The presence of sediment, epiphytes or epibionts in the fronds of the macroalgae was also examined.

\subsection{Mollusc assemblage}

To analyze the structure of the mollusc assemblage, the following data were obtained: composition and number of species, total abundance and percentage of individuals (N) of each species, Shannon-Wiener diversity index (H'), Pielou's equitability (J'), Margalef richness index (D) and Simpson's dominance index $(\lambda)$. These values were calculated using the Primer 6 statistics program.

The determination of the proportion of juveniles and adults of the species was based on the appearance of the shell and the mean size parameters found in the scientific literature (e.g. Hartmann, 2006; Mikkelsen and Bieler, 2008; Rios, 2009; Thomé et al., 2010; Tunnell Junior et al., 2010). Micromolluscs were considered those species that have a maximum size of $5 \mathrm{~mm}$ as adults, following the criterion suggested by Geiger et al. (2007). 
In the analysis of the size structure of the small gastropod Parvanachis obesa, the proportion of juveniles and adults present in each macroalgae was determined based on measurements of each specimen. Here we considered adults individuals larger than $3.5 \mathrm{~mm}$ length.

\section{Results}

Both studied algae, Gracilaria domingensis and G. cuneata, had an appearance of hanging shrub with flat and branched thallus. They were established themselves in the mangrove muddy substrate, near the margins of the main river channel. They have a prostrate habit, with no erect thallus, probably due to the persistent water currents in the main river channel. Despite being similar, these two species can be distinguished by the branching level, with G. domingensis (Figure 2a) being more branched and its branches more finely divided and G. cuneata (Figure 2b) being less branched with a coriaceous texture. Samples of the two species contained a large amount of sediment, which would help in harbouring many organisms, mainly micromolluscs. In addition, fronds of $G$. domingensis were found to harbour a large amount of sessile epibionts, such as ascidians and sponges, and also many vagile polychaetes, ophiuroids and malacostracans. On the other hand, in the samples of $G$. cuneata, there were practically no animal epibionts, but only epiphytic algae, mainly Ulva sp., Acanthophora sp. and $G$. domingensis.

A total of 1,490 molluscs belonging to 29 families were recorded in the samples, of which 18 were gastropods, 10 bivalves and one polyplacophoran (Table 1). In total, 56 species were found in the fronds of the two macroalgae, with greater richness and species diversity in G. cuneata $\left(\mathrm{D}=7.48, \mathrm{H}^{\prime}=1.25\right)$. Gracilaria domingensis displayed less richness and diversity, but a greater abundance of particular species, resulting in greater dominance $(\lambda=0.42)$ (Table 2). From the 1,490 specimens recorded, 1,112 were micromolluscs (less than $5 \mathrm{~mm}$ long), representing 74.63\% of the malacofauna found in the two macroalgae (Table 2).

A total of 1,081 molluses belonging to 25 species of 15 families were found in the fronds of $G$. domingensis $\left(\mathrm{J}^{\prime}=0.42, \lambda=0.42\right.$ ) (Table 2). Among them, 1,067 were gastropods (representing 98.7\%), 13 bivalves (1.2\%) and one polyplacophoran $(0.09 \%)$. The most abundant families were Columbellidae, Neritidae, Pyramidellidae, Cerithiidae and Triphoridae (Figure 3a). Columbellidae and Pyramidellidae had the highest species richness, each with five species, and Tellinidae with three. The most abundant 13 species comprised 787 specimens of molluscs, representing $72.80 \%$ of the total recorded for this algal species. There were also three juveniles $(0.27 \%)$ of typically larger sized species: Eurytellina lineata (Turton, 1819), Angulus versicolor (De Kay, 1843) and A. sybariticus (Dall, 1881). The most abundant species associated with $G$. domingensis were Parvanachis obesa (651 individuals), Neritina virginea (Linnaeus, 1758) (251), Astyris lunata (Say, 1826) (45), Boonea jadisi (Olsson \& McGinty, 1958) (25) and Costoanachis sparsa (Reeve, 1859) (18) (Table 1).

A total of 409 molluscs of 46 species, belonging to 24 families were collected from $G$. cuneata, being 388 gastropods (representing $94.86 \%$ of the total) and 21 bivalves $(5.13 \%)$. The families with the greatest abundance were Columbellidae, Pyramidellidae, Neritidae, Triphoridae and Cerithiidae (Figure 3b). Species richness was highest in Pyramidellidae (13 species) followed by Columbellidae (5), Rissoidae (4), and Veneridae (3). The most abundant species were Parvanachis obesa (96 specimens), followed by Neritina virginea (42), Marshallora nigrocincta (C. B. Adams, 1839) (41), Bittiolum varium (Pfeiffer, 1840) (34) and Turbonilla sp.1 (32) (Table 1). Among these molluscs, 325 were micromolluscs $(79.46 \%$ of the malacofauna living in the alga), representing 27 species (Table 2). Meanwhile, there were 12 young individuals of eight macromollusc species - Argopecten gibbus (Linnaeus, 1758), Pinctada
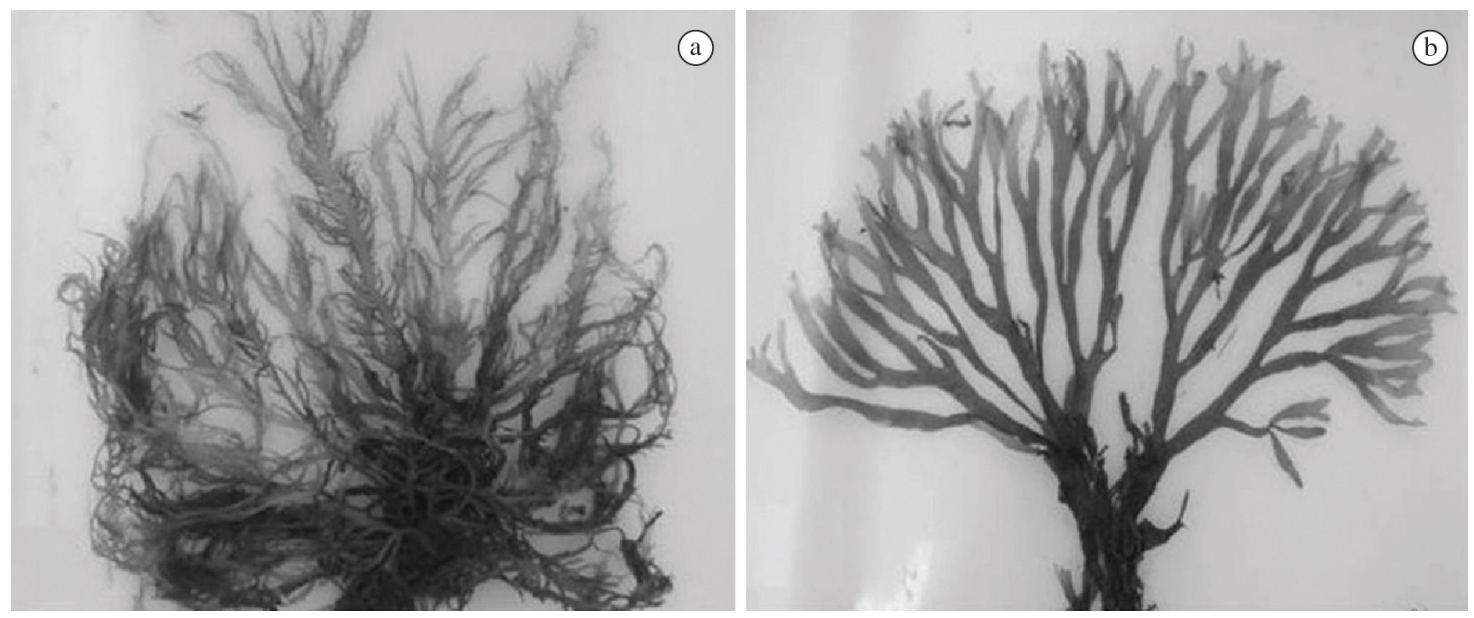

Figure 2. Aspects of the fronds of the macroalgae (a) Gracilaria domingensis and (b) Gracilaria cuneata from Tubarão River, Macau, State of Rio Grande do Norte, NE Brazil. Photographs by Romilda Queiroz. 
Table 1. Number of individuals (N) and Relative abundance (RA) of the molluscan species collected in association with the algae Gracilaria domingensis and G. cuneata at Tubarão River, Macau, State of Rio Grande do Norte, NE Brazil.

\begin{tabular}{|c|c|c|c|c|c|}
\hline \multirow[t]{2}{*}{ Class/Family/Species } & \multirow[t]{2}{*}{$\begin{array}{c}\text { Vouchers } \\
\text { (UEPB.MOL.) }\end{array}$} & \multicolumn{2}{|c|}{$\begin{array}{c}\text { Gracilaria } \\
\text { domingensis } \\
\text { (dry season) }\end{array}$} & \multicolumn{2}{|c|}{$\begin{array}{l}\text { Gracilaria cuneata } \\
\text { (rainy season) }\end{array}$} \\
\hline & & $\mathbf{N}$ & RA (\%) & $\mathbf{N}$ & RA (\%) \\
\hline \multicolumn{6}{|l|}{ ISCHNOCHITONIDAE } \\
\hline Unidentified Ischnochitonidae & 462 & 1 & 0.09 & - & - \\
\hline \multicolumn{6}{|l|}{ NERITIDAE } \\
\hline Neritina virginea (Linnaeus, 1758) & 445,442 & 251 & 23.22 & 42 & 10.27 \\
\hline \multicolumn{6}{|l|}{ EULIMIDAE } \\
\hline Melanella sarsi (Bush, 1909) & 453 & - & - & 1 & 0.25 \\
\hline \multicolumn{6}{|l|}{ COLUMBELLIDAE } \\
\hline Parvanachis obesa (C. B. Adams, 1845) & 422,439 & 651 & 60.22 & 96 & 23.47 \\
\hline Astyris lunata (Say, 1826) & 429,417 & 45 & 4.17 & 4 & 0.98 \\
\hline Costoanachis sparsa (Reeve, 1859) & 427,418 & 18 & 1.67 & 13 & 3.18 \\
\hline Costoanachis sertulariarum (d'Orbigny, 1839) & 459 & - & - & 3 & 0.73 \\
\hline Costoanachis sp. & 441 & 3 & 0.28 & - & - \\
\hline Astyris strix (Watson, 1882) & 466 & 1 & 0.09 & - & - \\
\hline \multicolumn{6}{|l|}{ LITIOPIDAE } \\
\hline Alaba incerta (d'Orbigny, 1841) & 421,440 & 3 & 0.28 & 8 & 1.96 \\
\hline \multicolumn{6}{|l|}{ CERITHIOPSIDAE } \\
\hline Cerithiopsis greenii (C. B. Adams, 1839) & 424 & - & - & 9 & 2.2 \\
\hline \multicolumn{6}{|l|}{ CYLICHNIDAE } \\
\hline Cylichnella bidentata (d'Orbigny, 1841) & 432 & - & - & 2 & 0.49 \\
\hline \multicolumn{6}{|l|}{ CERITHIIDAE } \\
\hline Bittiolum varium (Pfeiffer, 1840) & 423,416 & 15 & 1.39 & 34 & 8.32 \\
\hline \multicolumn{6}{|l|}{ TURRIDAE } \\
\hline Pyrgocythara albovittata (C. B. Adams, 1845) & 426,454 & 1 & 0.09 & 1 & 0.25 \\
\hline \multicolumn{6}{|l|}{ TRIPHORIDAE } \\
\hline Marshallora nigrocincta (C. B. Adams, 1839) & 438,415 & 11 & 1.02 & 41 & 10.02 \\
\hline \multicolumn{6}{|l|}{ PYRAMIDELLIDAE } \\
\hline Turbonilla cf. fasciata (d'Orbigny, 1840) & 471,477 & 13 & 1.20 & 11 & 2.69 \\
\hline Boonea jadisi (Olsson \& McGinty, 1958) & 456,419 & 25 & 2.32 & 4 & 0.98 \\
\hline Turbonilla cf. elegans (d’Orbigny, 1841) & 470,469 & 7 & 0.65 & 9 & 2.2 \\
\hline Turbonilla cf. pupoides (d'Orbigny, 1841) & 474,479 & 7 & 0.65 & 8 & 1.96 \\
\hline Turbonilla cf. asperula Bush, 1899 & 467 & - & - & 1 & 0.25 \\
\hline Turbonilla cf. capixaba Pimenta \& Absalão, 2004 & 472 & - & - & 2 & 0.49 \\
\hline Eulimella sp. & 473 & - & - & 1 & 0.25 \\
\hline Turbonilla sp.1 & 468 & - & - & 32 & 7.82 \\
\hline Turbonilla sp.2 & 475 & - & - & 7 & 1.71 \\
\hline Turbonilla cf. textilis (Kurtz, 1860) & 480,478 & 5 & 0.46 & 20 & 4.89 \\
\hline Egila sp. & 465 & - & - & 1 & 0.25 \\
\hline Eulimastoma canaliculatum (C. B. Adams, 1850) & 458 & - & - & 2 & 0.49 \\
\hline Odostomia unidentata (Montagu, 1803) & 434 & - & - & 1 & 0.25 \\
\hline \multicolumn{6}{|l|}{ HIPPONICIDAE } \\
\hline Hipponix incurvus (Gmelin, 1791) & 433 & - & - & 1 & 0.25 \\
\hline \multicolumn{6}{|l|}{ CALYPTRAEIDAE } \\
\hline Crepidula plana Say, 1822 & 428 & - & - & 2 & 0.49 \\
\hline Bostrycapulus aculeatus (Gmelin, 1791) & 431 & - & - & 1 & 0.25 \\
\hline \multicolumn{6}{|l|}{ RISSOIDAE } \\
\hline Schwartziela catesbyana (d'Orbigny, 1842) & 420 & - & - & 9 & 2.2 \\
\hline Schwartziela bryerea (Montagu, 1803) & 435 & - & - & 4 & 0.98 \\
\hline Alvania sp. & 476 & - & - & 12 & 2.93 \\
\hline
\end{tabular}


Table 1. Continued...

\begin{tabular}{|c|c|c|c|c|c|}
\hline \multirow[t]{2}{*}{ Class/Family/Species } & \multirow[t]{2}{*}{$\begin{array}{c}\text { Vouchers } \\
\text { (UEPB.MOL.) }\end{array}$} & \multicolumn{2}{|c|}{$\begin{array}{c}\text { Gracilaria } \\
\text { domingensis } \\
\text { (dry season) }\end{array}$} & \multicolumn{2}{|c|}{$\begin{array}{l}\text { Gracilaria cuneata } \\
\text { (rainy season) }\end{array}$} \\
\hline & & $\mathbf{N}$ & RA (\%) & $\mathbf{N}$ & RA (\%) \\
\hline Alvania deliciosa (Jeffreys, 1884) & 484 & - & - & 4 & 0.98 \\
\hline HAMINOEIDAE & & & & & \\
\hline Atys riiseanus Mörch, 1875 & 425 & - & - & 2 & 0.49 \\
\hline BULLIDAE & & & & & \\
\hline Bulla striata Bruguiere, 1792 & 444 & 4 & 0.37 & - & - \\
\hline OLIVIDAE & & & & & \\
\hline Olivella minuta (Link, 1807) & 452 & 5 & 0.46 & - & - \\
\hline CONIDAE & & & & & \\
\hline Conus jaspideus (Gmelin, 1791) & 455 & 1 & 0.09 & - & - \\
\hline FASCIOLARIIDAE & & & & & \\
\hline Pleuroploca aurantiaca (Lamarck, 1816) & 181 & 1 & 0.09 & - & - \\
\hline VENERIDAE & & & & & \\
\hline Anomalocardia brasiliana (Gmelin, 1791) & 443,447 & 9 & 0.83 & 4 & 0.98 \\
\hline Chione sp. & 446 & - & - & 1 & 0.25 \\
\hline Transennella stimpsoni Dall, 1902 & 463 & - & - & 1 & 0.25 \\
\hline SOLECURTIDAE & & & & & \\
\hline Tagelus divisus (Spengler, 1794) & 449,448 & 1 & 0.09 & 1 & 0.25 \\
\hline PECTINIDAE & & & & & \\
\hline Argopecten gibbus (Linnaeus, 1758) & 450 & - & - & 4 & 0.98 \\
\hline CORBULIDAE & & & & & \\
\hline Caryocorbula caribaea (d'Orbigny, 1853) & 460 & - & - & 1 & 0.25 \\
\hline Caryocorbula cymella (Dall, 1881) & 437 & - & - & 1 & 0.25 \\
\hline PTERIIDAE & & & & & \\
\hline Pinctada imbricata Röding, 1798 & 451 & - & - & 1 & 0.25 \\
\hline MYIDAE & & & & & \\
\hline Sphenia fragilis (H. \& A. Adams, 1854) & 457 & - & - & 2 & 0.49 \\
\hline LUCINIDAE & & & & & \\
\hline Lucinoma filosa (Stimpson, 1851) & 430 & - & - & 1 & 0.25 \\
\hline TELLINIDAE & & & & & \\
\hline Angulus exerythrus (Boss, 1964) & 464 & - & - & 1 & 0.25 \\
\hline Eurytellina lineata (Turton, 1819) & 483 & 1 & 0.09 & - & - \\
\hline Angulus versicolor (De Kay, 1843) & 481 & 1 & 0.09 & - & - \\
\hline Angulus sybariticus (Dall, 1881) & 482 & 1 & 0.09 & - & - \\
\hline MYTILIDAE & & & & & \\
\hline Musculus lateralis (Say, 1822) & 461 & - & - & 2 & 0.49 \\
\hline NUCULIDAE & & & & & \\
\hline Nucula crenulata A. Adams, 1856 & 436 & - & - & 1 & 0.25 \\
\hline TOTAL $=56$ species & & 1081 & 100 & 409 & 100 \\
\hline
\end{tabular}

imbricata Röding, 1798, Angulus exerythrus (Boss, 1964), Crepidula plana Say, 1822, Chione sp., Lucinoma filosa (Stimpson, 1851), Transennella stimpsoni Dall, 1902 and Nucula crenulata A. Adams, 1856 -, accounting for $2.93 \%$. Parvanachis obesa was the most abundant species found in both sampled algae ( $\mathrm{N}=747$ specimens), from which 127 specimens were up to $3.5 \mathrm{~mm}$ in size, and were considered as juveniles.

Only 15 molluscan species occurred in both algae: the gastropods Parvanachis obesa, Neritina virginea, Astyris lunata, Costoanachis sparsa, Alaba incerta (d'Orbigny, 1841), Bittiolum varium, Pyrgocythara albovittata (C. B. Adams, 1845), Marshallora nigrocincta, Turbonilla cf. fasciata (d'Orbigny, 1840), Boonea jadisi, Turbonilla cf. elegans (d'Orbigny, 1841), Turbonilla $\mathrm{cf}$. pupoides (d'Orbigny, 1841) and Turbonilla cf. textilis (Kurtz, 1860), and the bivalves Anomalocardia brasiliana (Gmelin, 1791) and Tagelus divisus (Spengler, 1794) (Figure 4).

Parvanachis obesa (Figure 4a) corresponded to $60.22 \%$ of the molluscs found in G. domingensis and $23.47 \%$ in 
Table 2. Shannon-Wiener diversity (H'), Margalef's richness index (D), Pielou's equitability (J) and dominance $(\lambda)$, number of molluscan species, total number of molluscs ( $\mathrm{N}$ Total), frequency of mollusks for macroalgae (\%N Molluscs), total number $(\mathrm{N})$ and relative frequency of micromolluscs (adults measuring less than $10 \mathrm{~mm})(\% \mathrm{~N})$ found associated with the algae Gracilaria domingensis and G. cuneata at Tubarão River, Macau, State of Rio Grande do Norte, NE Brazil.

\begin{tabular}{|c|c|c|c|c|c|c|c|c|c|}
\hline \multirow[t]{2}{*}{ Macroalgae } & \multirow{2}{*}{$\begin{array}{l}\text { Diversity } \\
\text { (H') }\end{array}$} & \multirow{2}{*}{$\begin{array}{l}\text { Equitability } \\
\text { (J') }\end{array}$} & \multirow{2}{*}{$\begin{array}{l}\text { Richness } \\
\text { (D) }\end{array}$} & \multirow{2}{*}{$\begin{array}{c}\text { Dominance } \\
(\lambda)\end{array}$} & \multirow{2}{*}{$\begin{array}{c}\mathrm{N}^{\mathbf{0}} \\
\text { Species }\end{array}$} & \multirow[t]{2}{*}{ N Total } & \multirow{2}{*}{$\begin{array}{c}\% \mathbf{N} \\
\text { Molluscs }\end{array}$} & \multicolumn{2}{|c|}{ Micromolluscs } \\
\hline & & & & & & & & $\mathbf{N}$ & $\% \mathbf{N}$ \\
\hline $\begin{array}{l}\text { Gracilaria } \\
\text { domingensis (dry } \\
\text { season) }\end{array}$ & 0.59 & 0.42 & 3.44 & 0.42 & 25 & 1081 & 72.55 & 787 & 72.80 \\
\hline $\begin{array}{l}\text { Gracilaria cuneata } \\
\text { (rainy season) }\end{array}$ & 1.25 & 0.75 & 7.48 & 0.097 & 46 & 409 & 27.45 & 325 & 79.46 \\
\hline TOTAL & - & - & - & - & 56 & 1490 & & 1112 & 74.63 \\
\hline
\end{tabular}
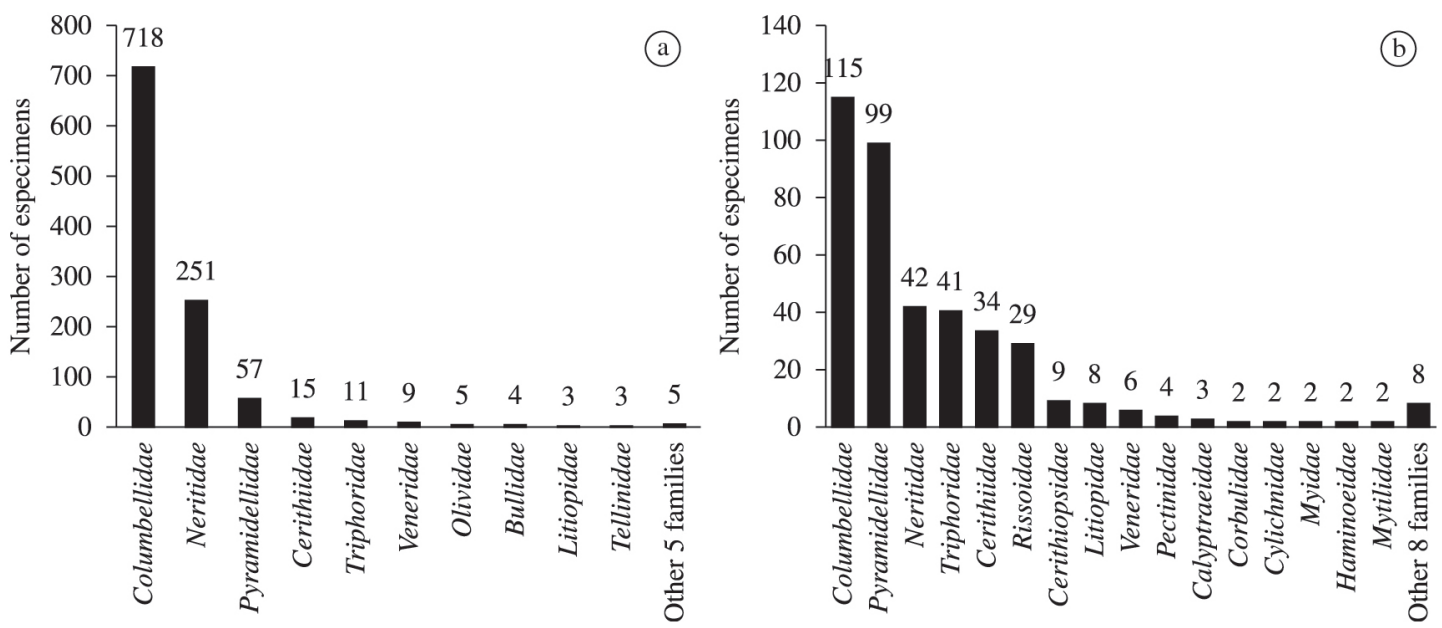

Figure 3. Number of individuals by mollusc family associated to the macroalgae (a) Gracilaria domingensis (collected in the dry season) and (b) Gracilaria cuneata (collected in the rainy season) at Tubarão River, Macau, State of Rio Grande do Norte, NE Brazil.

G. cuneata. The population found in $G$. domingensis had a mean shell length of $4.14 \pm 0.76 \mathrm{~mm}$, in the range of 1-10 mm. Although juveniles were numerous (shell length $\sim 3.5 \mathrm{~mm}$ ), there was a predominance of adults $(>3.5 \mathrm{~mm})$, representing $84.49 \%$ of the total (Table 3). In G. cuneata, P. obesa exhibited a mean shell size of $3.97 \pm 1.25 \mathrm{~mm}$, within a range of 0.5 to $5 \mathrm{~mm}$ in length. In contrast to the specimens found in $G$. domingensis, which displayed a predominance of shell size around $4 \mathrm{~mm}$, in G. cuneata there was a predominance both of larger individuals $(5 \mathrm{~mm})$ and very small ones $(0.5 \mathrm{~mm})$. It is important to note that the total number of $P$. obesa obtained from $G$. domingensis was almost seven times that of $G$. cuneata. In the latter alga, there was also a predominance of adults, making up $72.92 \%$ of the total (Table 3 ).

The shell coloration of $P$. obesa showed three distinct basic colour patterns: specimens with clear coloration, whitish-yellow with clear spots (pattern C) (Figure 5a); whitish specimens, with brown circle stripes (pattern L) (Figure 5b); and dark-brown-coloured individuals (pattern E) (Figure 5c). Based on these patterns, most $P$. obesa individuals found in $G$. domingensis showed pattern $\mathrm{L}$
(46.82\%) followed by E (43.48\%), while pattern L was dominant in G. cuneata (53.12\%) (Table 3).

\section{Discussion}

The macroalgae of the genus Gracilaria studied in the Tubarão River encompass a rich and diverse assemblage of molluscs, composed predominantly of micromolluscs. In comparison with some of the main studies conducted in Brazil on the malacofauna associated with macroalgae (e.g. Jacobucci et al., 2006; Lacerda et al., 2009; Leite et al., 2009), the present study found the greatest number of species.

Tubarão River estuary contains a hypersaline mangrove, which creates highly adverse conditions, thereby restricting the resident fauna even further (Dias, 2006). However, the results obtained in the present study diverged from this pattern because they showed that this habitat presents an intriguing environment for investigation.

The high diversity and richness of molluscs in G. cuneata was due to the low abundance of each species. On the other hand, diversity and richness were low in $G$. domingensis because $P$. obesa was strongly dominant (more than $60 \%$ of the total malacofauna). 
Such a pattern in not in accordance with Werner and Hall (1977), who state that algae that have a structure with more complex fronds can offer a greater surface area for periphyton and other food items, as well as for the establishment of many epiphytic species by protecting them against predators and, therefore, these complex algae can harbour a greater diversity of organisms than less complex algae. However, this was not evident in the

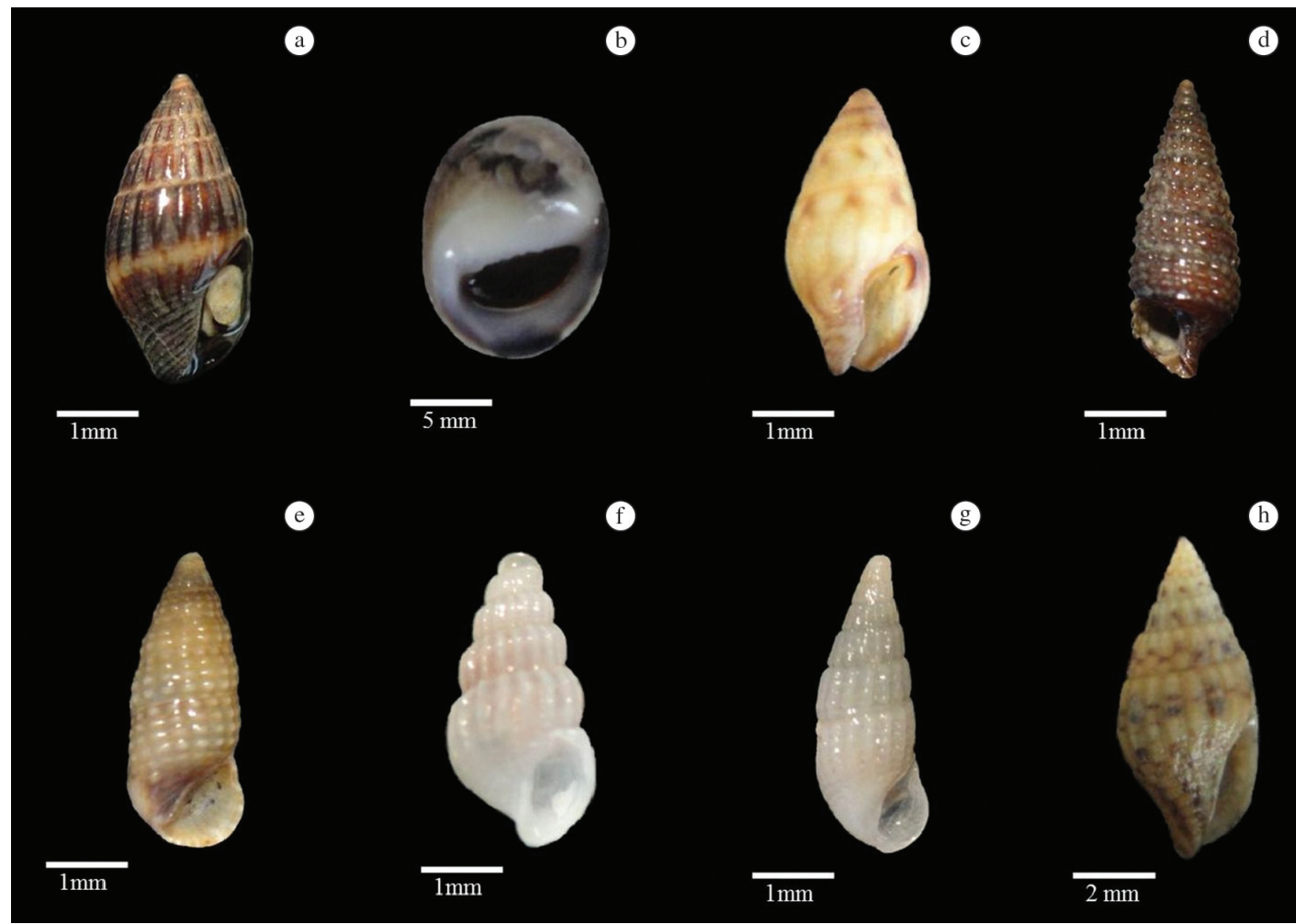

Figure 4. Most abundant species found associated with the algae Gracilaria domingensis and G. cuneata at Tubarão River, Macau, State of Rio Grande do Norte, NE Brazil: (a) Parvanachis obesa, (b) Neritina virginea, (c) Astyris lunata, (d) Marshallora nigrocincta, (e) Bittiolum varium, (f) Turbonilla sp.1, (g) Boonea jadisi e (h) Costoanachis sparsa. Photographs by Romilda Queiroz.
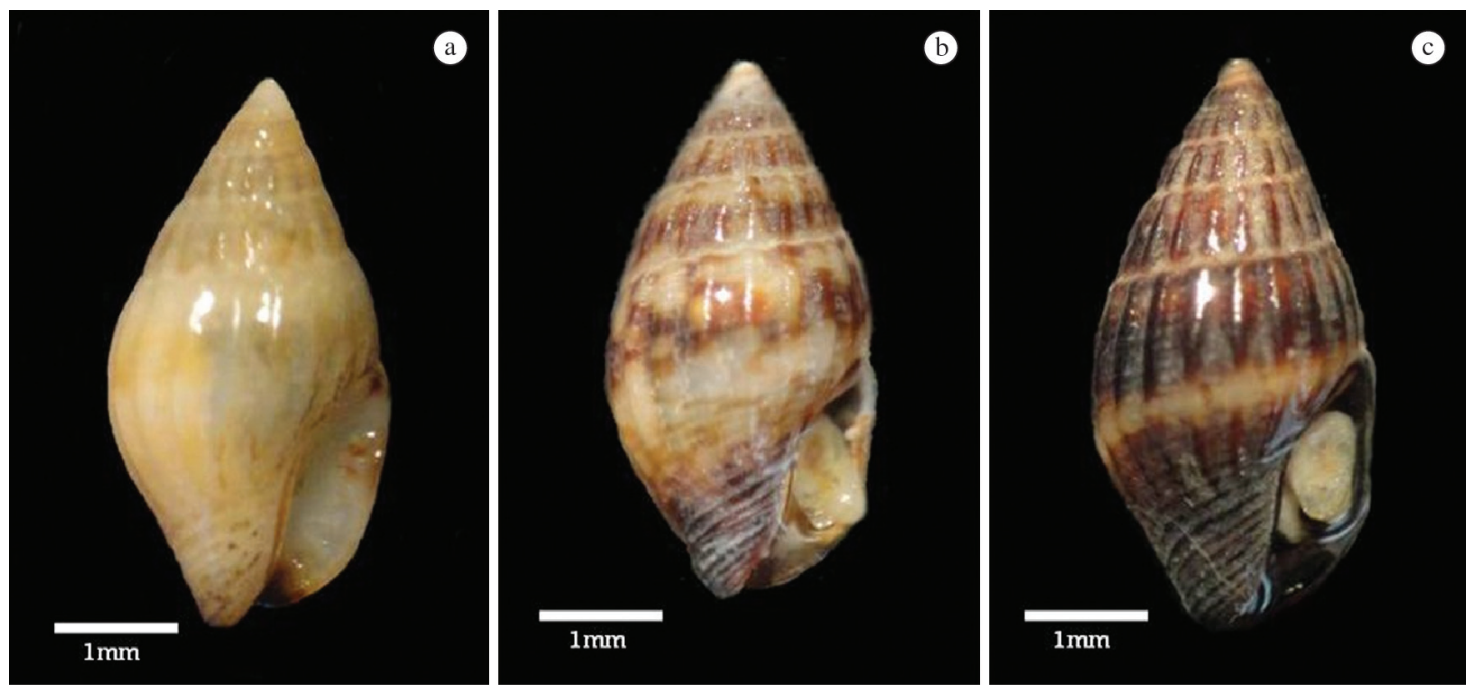

Figure 5. Colour patters recorded for Parvanachis obesa associated with the algae Gracilaria domingensis and G. cuneata from Tubarão River, Macau, State of Rio Grande do Norte, NE Brazil. (a) Pattern C: whitish yellow with clear spots. (b) Pattern L: whitish with brown circle stripes. (c) Pattern E: dark-colored with a brown colour. Photographs by Romilda Queiroz. 
Table 3. Size and colour patterns of Parvanachis obesa associated to the macroalgae Gracilaria domingensis and G. cuneata at Tubarão River, Macau, State of Rio Grande do Norte, NE Brazil. N=number of specimens, \% RA=relative abundance of individuals, $\mathrm{SD}=$ standard deviation.

\begin{tabular}{|c|c|c|c|c|c|c|c|c|c|c|c|}
\hline \multirow{3}{*}{ Macroalgae } & \multicolumn{6}{|c|}{ Colour Patterns } & \multicolumn{4}{|c|}{ Size $(\mathrm{mm})$} & \multirow{3}{*}{ Mean \pm SD } \\
\hline & \multicolumn{2}{|c|}{ Clear } & \multicolumn{2}{|c|}{ Striped } & \multicolumn{2}{|c|}{ Dark } & \multicolumn{2}{|c|}{$\begin{array}{c}\text { Juveniles } \\
(<3.5 \mathrm{~mm})\end{array}$} & \multicolumn{2}{|c|}{$\begin{array}{c}\text { Adults } \\
(>3.5 \mathrm{~mm})\end{array}$} & \\
\hline & $\mathbf{N}$ & $\% \mathrm{~N}$ & $\mathbf{N}$ & $\% \mathrm{~N}$ & $\mathbf{N}$ & $\% \mathrm{~N}$ & $\mathbf{N}$ & $\% \mathrm{~N}$ & $\mathbf{N}$ & $\% \mathrm{~N}$ & \\
\hline $\begin{array}{l}\text { Gracilaria } \\
\text { domingensis } \\
\text { (dry season) }\end{array}$ & 63 & 9.68 & 305 & 46.85 & 283 & 43.47 & 101 & 15.51 & 550 & 84.49 & $3.97 \pm 1.25$ \\
\hline $\begin{array}{l}\text { Gracilaria } \\
\text { cuneata } \\
\text { (rainy season) }\end{array}$ & 16 & 16.67 & 51 & 53.12 & 29 & 30.21 & 26 & 27.08 & 70 & 72.92 & $4.14 \pm 0.77$ \\
\hline TOTAL & 79 & 10.57 & 356 & 47.66 & 312 & 41.77 & 127 & 17 & 620 & 83 & \\
\hline
\end{tabular}

present study, as the alga species with a visually more complex structure showed less diversity and richness of molluscs, suggesting that other factors were influencing the structure of the mollusc assemblage. Surely, the finely branched thallii colonized by many epiphytic organisms in $G$. domingensis were very favourable to the establishment of the juvenile population of the gastropod P. obesa. Another inference can be possible: as $G$. domingensis occurs mainly in the dry season, its finely branches would keep higher humidity which, in turn, attracted most associated animals, including this gastropod.

The size and type of structure of the alga-substrate can also be important for the establishment of large species. According to the studies of other macroalgae of foliaceous or laminar appearance (e.g. Jacobucci et al., 2006; Lacerda et al., 2009; Leite et al., 2009), there is a predominance of bivalves. However, in the two species of macroalgae collected in Tubarão River, there was a predominance of gastropods, with the largest quantity of bivalves being found only in G. cuneata. This could be related to the fact that many species of bivalves are larger as adults and need more space for fixation, and that they attach themselves to the substrate by means of the byssus, thus requiring a larger surface for support.

One of the possible factors affecting the community is the presence of epiphytic algae, which were plentiful in G. cuneata. According to Pereira et al. (2010), the epiphytes are important because they can create complexity and increase the surface area of the algal host, offering more space for the establishment of periphyton and other organisms. However, although $G$. cuneata hosted a greater quantity of epiphytic algae, it must be noted that the abundance of the species found in it was low, because there was only one specimen for most species.

Meanwhile, the fact that the algae utilized in this study were established in the environment with a prostrate habit could also be a factor influencing the abundance of malacofauna, mainly in $G$. domingensis. In general, prostrate algae, in the form of turfs or stolons, arbustive or branched, retain a greater quantity of sediment, which can contain large numbers of micromolluscs (Masunari and Forneris, 1981; Kershner and Lodge, 1990). Thus, it is important to understand how these macroalgal structural characteristics affect the composition and abundance of species. It is probably the case that the most branched and most complex algae provide a surface for juveniles of medium- and large-sized species (Kershner and Lodge, 1990), as occurred in G. domingensis. This macroalga hosted juvenile individuals of species such as Pleuroploca aurantiaca (Lamarck, 1816), Bulla striata Bruguiere, 1792 and Anomalocardia brasiliana, which can grow to a large size. On the other hand, juveniles of these large species were also recorded in G. cuneata, mainly bivalves such as Argopecten gibbus and Pinctada imbricata.

There could have been competition pressure in the case of the epiphytes found in G. cuneata, influencing the availability of space for these larger organisms. Some studies aimed at analysing competition between algae discuss how both structure and the production of allopathic substances from these epiphytes are able to determine relationships with these environments (Kim, 2002; Leite and Turra, 2003), which can also determine the organisms suitable for colonizing a particular algal species.

However, it is possible that the structure of the malacofauna of the phytal community in the hypersaline mangrove has been strongly influenced by the relationships within the trophic niche, because macroalgae provide shelter and protection against predators, which might otherwise act to reduce diversity in these microhabitats. It should be noted that predators can play an important role in the formation of trophic niche relationships and in the regulation of diversity within communities (Ricklefs, 2003). It is possible that the shelter offered by the greater structural complexity of the algal species has been positive through greater dietary specialization or ecological restriction of the species of molluscs associated with them.

The Columbellidae comprise herbivorous and carnivorous species, but Astyris lunata and Parvanachis obesa, which were the main representatives of this family in the two algae, are carnivorous, with the former being a specialist on tunicates (Paine, 1966; Locke et al., 2007). This information is interesting to note because, in the samples of $G$. domingensis, there were abundant tunicates and 
sponges, as well as other invertebrates such as polychaetes and ophiuroids.

As noted, Parvanachis obesa was the most abundant mollusc species in the two macroalgae, especially in G. domingensis, comprising more than half of the malacofauna found in this alga. According to Leite et al. (2009), the abundance of $P$. obesa associated with the green algae Caulerpa racemosa was very low, suggesting that the species may prefer red algae. In the studied algae, it was possible to determine that the majority of the specimens found were adults, although the proportion of juveniles was greater in $G$. cuneata, suggesting that these algae represent a permanent habitat for this species. Tunnell Junior et al. (2010) notes that $P$. obesa has an average size of 5 or $6 \mathrm{~mm}$, but the data obtained for the two macroalgae in the present study revealed a mean size of $4 \mathrm{~mm}$ for the two algae, with a total range of 0.5 to $6 \mathrm{~mm}$. Additionally, an analysis of the shell coloration patterns showed that this species does not undergo ontogenetic variation of colour. However, there was a predominance of shells with horizontal stripes and of shells with a dark coloration, and specimens with a clear colour had the largest sizes. In the literature, there are no studies that discuss or explain the occurrence of these coloration patterns in P. obesa, and the majority of reports citing this species give only descriptions. Although it was first described in 1845, only a few studies have been conducted on the biology of this species, of which almost all refer to surveys providing descriptions or palaeontological findings (Weisboard, 1962; Benkendorfer and Soares-Gomes, 2009).

Other families that merit attention are Neritidae, Triphoridae and Cerithiidae, which were well represented in terms of abundance of individuals. Within Neritidae and Cerithiidae, there was a large abundance of Neritina virginea and Bittiolum varium, which can be explained by the fact that these species are microherbivores (Meirelles and Matthews-Cascon, 2003). In this case, their presence is possibly due to the large periphyton resource hosted by these algae, mainly in the estuarine environment. The Triphoridae, whose members are considered sponge feeders (Albano et al., 2011), was the most abundant in G. cuneata, in which sponges were scarce. Thus, it is possible that, in the hypersaline estuarine environment, these micromolluscs utilize other food items in their diet according to the availability in their algal microhabitat.

The seasonality of reproduction and the recruitment period is an important question to be considered when analyzing the composition of the malacofauna of the phytal community. Leite and Turra (2003) pointed out that the density of the associated fauna can be influenced by patterns in the variation of dominant faunistic groups. The presence of crustaceans, polychaetes and ophiuroids was observed in $G$. domingensis, while in G. cuneata, malacofauna was dominant when compared to other invertebrate taxa, which can be explained by a probable seasonal pattern of occupation by different groups of invertebrates. In the period in which the samples of G. cuneata were collected (rainy season), few competitors and predators might have favoured the finding of a greater quantity of species of molluscs. Some species of algae can represent a specific substrate for many species of epifauna, which can thereby affect their abundance and distribution in a particular environment (Chemello and Milazzo, 2002). Hewitt et al. (2005) showed the relevance of habitat structure observed at small scales, mainly in locations composed of unconsolidated substrates. This type of microhabitat can be of even greater value for molluscs. These microenvironments can be essential for micromolluses and for macromollusc juveniles.

In other studies conducted in Brazil on the phytal community (e.g. Jacobucci et al., 2006; Lacerda et al., 2009; Leite et al., 2009), Bittiolum varium, columbellids and pyramidellids, for example, represented the most abundant and frequent species, which reinforces even further the importance of macroalgae for many organisms, especially small species. This fauna is composed of species that have an average size of 2 to $3 \mathrm{~mm}$ and represent a great challenge in the detection and identification of specimens, which are therefore often underestimated in faunistic surveys.

Historically, greater emphasis and importance have been given to organisms that are large and considered more attractive. However, the greatest part of species richness concerns organisms that are small and appears cryptic (Mikkelsen and Cracraft, 2001), and this is no different for malacofauna. A large part of the information and reports in the literature is concentrated on macromolluscs, whereas micromolluscs are seldom studied and subsampled (Albano et al., 2011). A thorough investigation of the microfauna associated with different marine microhabitats could reveal the presence of species new to science. In this study, the large number of species identified at least to genus level indicates that there is a considerable possibility of finding new records of species distributions and new species for science.

The present study demonstrated the importance of these macroalgae for the mollusc assemblage, because they shelter a large variety of organisms, with micromolluscs being among the dominant groups. In addition to the juveniles of medium- and large-sized mollusc species, the substantial presence of micromolluscs in the samples of $G$. domingensis and G. cuneata showed that these algae harbour a small "world" composed of species so small that they are often neglected in faunistic surveys

The several factors determining the composition of species in the phytal community need to be identified, pointing out the necessity of conducting more studies aimed at achieving better understanding. It is also important to compare the results obtained between environments that are differentially influenced by these factors, mainly in mangroves, where there have been few studies on the molluscs associated with algae. Thus, this point should be the key to an understanding of the composition and relationships of the "microworld" hosted by these macroalgae. 


\section{Acknowledgements}

We are grateful to our colleagues Ellori Laíse Silva Mota, Rafaela Cristina de Souza Duarte and Jacicleide Macedo Oliveira for their help in sorting the material studied, and to Luis Carlos and Leidson Allan for their essential support in the fieldwork. We are also thankful to Leidson Allan for identification of the algae studied, and to Dona Dalci and family for their logistical support in the community of Diogo Lopes. CNPq (Brazilian Research Council) through Projeto Universal (Process Nr 479213/2010-0) and Programa Institucional de Apoio à Pesquisa da UEPB/ PROPESQ (Process Nr 115/2011), both coordinated by T. L. P. Dias, financially supported this study. We thank one anonymous referee for valuable suggestions on the manuscript. Dr. A. Leyva helped with English translation and editing of the manuscript.

\section{References}

ALBANO, PG., SABELLI, B. and BOUCHET, P., 2011. The challenge of small and rare species in marine biodiversity surveys: microgastropod diversity in a complex tropical coastal environment. Biodiversity and Conservation, vol. 20, no. 13, p. 3223-3237. http://dx.doi.org/10.1007/s10531-011-0117-x.

AZEVEDO, JMN., 1992. Algae-associated marine molluscs in the Azores. Biological Journal of the Linnean Society. Linnean Society of London, vol. 46, no. 1-2, p. 177-187. http://dx.doi. org/10.1111/j.1095-8312.1992.tb00859.x.

BENKENDORFER, G. and SOARES-GOMES, A., 2009. Biogeography and biodiversity of gastropod molluses from the eastern Brazilian continental shelf and slope. Latin American Journal of Aquatic Research, vol. 37, no. 2, p. 143-159. http:// dx.doi.org/10.3856/vol37-issue2-fulltext-3.

CHEMELLO, R. and MILAZZO, M., 2002. Effect of algal architecture on associated fauna: some evidence from phytal molluscs. Marine Biology, vol. 140, no. 5, p. 981-990. http:// dx.doi.org/10.1007/s00227-002-0777-x.

DIAS, TLP., 2006. Os peixes, a pesca e os pescadores da Reserva de Desenvolvimento Sustentável Ponta do Tubarão (Macau-Guamaré/ $R N)$, Brasil. João Pessoa: Universidade Federal da Paraíba. 168 p. Tese de Doutorado em Ciências Biológicas (Zoologia).

DIAS, TLP., ROSA, RS. and DAMASCENO, LCP., 2007. Aspectos socioeconômicos, percepção ambiental e perspectivas das mulheres marisqueiras da Reserva de Desenvolvimento Sustentável Ponta do Tubarão (Rio Grande do Norte, Brasil). Gaia Scientia, vol. 1, no. 1, p. 25-35.

EDGAR, GJ., 1983a. The ecology of south-east Tasmanian phytal animal communities. III. Patterns of species diversity. Journal of Experimental Marine Biology and Ecology, vol. 70, no. 2, p. 181-203. http://dx.doi.org/10.1016/0022-0981(83)90129-6.

EDGAR, GJ., 1983b. The ecology of south-east Tasmanian phytal animal communities. II. Seasonal change in plant and animal populations. Journal of Experimental Marine Biology and Ecology, vol. 70, no. 2, p. 159-179. http://dx.doi.org/10.1016/00220981(83)90128-4.

GEIGER, DL., MARSHALL, BA., PONDER, WF., SASAKI, T. and WARÉN, A., 2007. Techniques for collecting, handling, preparing, storing and examining small molluscan specimens. Molluscan Research, vol. 27, no. 1, p. 1-50.

HACKER, SD. and STENECK, RS., 1990. Habitat architecture and the abundance and body-size-dependent habitat selection of a phytal amphipod. Ecology, vol. 71, no. 6, p. 2269-2285. http:// dx.doi.org/10.2307/1938638.

HARTMANN, T.,2006. Bivalve Seashells of Florida: an identification guide to the common species of Florida and the Southeast. Tampa: Anadara Press. 183 p.

HAUSER, A., ATTRILL, MJ. and COTTON, PA., 2006. Effects of habitat complexity on the diversity and abundance of macrofauna colonizing artificial kelp holdfasts. Marine Ecology Progress Series, vol. 325, p. 93-100. http://dx.doi.org/10.3354/meps325093.

HEWITT, JE., THRUSH, SF., HALLIDAY, J. and DUFFY, C., 2005. The importance of small-scale habitat structure for maintaining beta diversity. Ecology, vol. 86, no. 6, p. 1619-1626. http://dx.doi.org/10.1890/04-1099.

Instituto de Desenvolvimento Econômico e Meio Ambiente do Rio Grande do Norte - IDEMA, 2004. Mapeamento geoambiental da Reserva de Desenvolvimento Sustentável Ponta do Tubarão. Natal: IDEMA. Relatório Técnico.

JACOBUCCI, GB., GUTH, AZ., TURRA, A., MAGALHÃES, CA., DENADAI, MR., CHAVES, AMR. and SOUZA, ECF., 2006. Levantamento de Mollusca, Crustacea e Echinodermata associados a Sargassum spp. na Ilha da Queimada Pequena, Estação Ecológica dos Tupiniquins, litoral sul do Estado de São Paulo, Brasil. Biota Neotropica, vol. 6, no. 2. http://dx.doi. org/10.1590/S1676-06032006000200023.

KERSHNER, MW. and LODGE, DM., 1990. Effect of substrate architecture on aquatic gastropod-substrate associations. Journal of the North American Benthological Society, vol. 9, no. 4, p. 319-326. http://dx.doi.org/10.2307/1467899.

KIM, JH., 2002. Mechanisms of competition between canopy-forming and turf-forming intertidal algae. Algae (Korean Phycological Society), vol. 17, no. 1, p. 33-39. http://dx.doi.org/10.4490/ ALGAE.2002.17.1.033

LACERDA, MB., DUBIASKI-SILVA, J. and MASUNARI, S., 2009. Malacofauna de três fitais da Praia de Caiobá, Matinhos, Paraná. Acta Biológica Paranaense, vol. 38, no. 1-2, p. 59-74.

LEITE, FPP., TAMBOURGI, MR. and CUNHA, CM., 2009. Gastropods associated with the green seaweed Caulerpa racemosa, on two beaches of the Northern coast of the State of São Paulo, Brazil. Strombus, vol. 16, no. 1-2, p. 1-10.

LEITE, FP. and TURRA, A., 2003. Temporal variation in Sargassum biomass, Hypnea epiphytism and associated fauna. Brazilian Archives of Biology and Technology, vol. 46, no. 4, p. 665-671. http://dx.doi.org/10.1590/S1516-89132003000400021.

LOCKE, A., HANSON, JM., ELLIS, KM., THOMPSON, J. and ROCHETTE, R., 2007. Invasion of the southern Gulf of St. Lawrence by the clubbed tunicate (Styela clava Hardman): Potential mechanisms for invasions of Prince Edward Island estuaries. Journal of Experimental Marine Biology and Ecology, vol. 342, no. 1, p. 69-77. http://dx.doi.org/10.1016/j.jembe.2006.10.016.

LUCENA, LAF., 2012. Estrutura e composição de macroalgas de manguezais hipersalinos do Rio Grande do Norte, Brasil: diversidade e suas correlações com as variáveis ambientais. Campina Grande: Universidade Estadual da Paraíba. 141 p. Dissertação de Mestrado em Ecologia e Conservação. 
MASUNARI, S. and FORNERIS, L., 1981. O ecossistema fital: uma revisão. In Seminários de Biologia Marinha, 1981. Rio de Janeiro. Rio de Janeiro: Academia Brasileira de Ciências. p. 149.

MEIRELLES, CAO. and MATTHEWS-CASCON, H., 2003. Relations between shell size and radula size in marine prosobranchs (Mollusca: Gastropoda). Thalassas, vol. 19, no. 2, p. 45-53.

MIKKELSEN, PM. and CRACRAFT, J., 2001. Marine biodiversity and the need for systematic inventories. Bulletin of Marine Science, vol. 69 , no. 2 , p. $525-534$

MIKKELSEN, PM. and BIELER, R.,2008. Seashells of Southern Florida - Living marine mollusks of the Florida Keys and adjacent regions: Bivalves. Princeton: Princeton University Press. 496 p.

PAINE, RT., 1966. Food web complexity and species diversity. American Naturalist, vol. 100, no. 910, p. 65-75. http://dx.doi. org/10.1086/282400.

PEREIRA, PHC., BIASI, PC. and JACOBUCCI, GB., 2010. Dinâmica populacional e distribuição espacial de Tricolia affinis (Mollusca: Gastropoda) associados a Sargassum spp. no litoral norte de São Paulo. Revista Brasileira de Zoociências, vol. 12, no. 1, p. $7-16$.

RICKLEFS, R., 2003. A Economia da Natureza. 5. ed. Rio de Janeiro: Guanabara Koogan. 542 p.

RIOS, EC., 2009. Compendium of Brazilian Sea Shells. Rio Grande: FURG. 676 p.

THOMÉ, JW., BERGONCI, PEA. and GIL, GM., 2010. As conchas das nossas praias. Pelotas: Editora USEB. 223 p.

TUNNELL JUNIOR, JW., ANDREWS, J., BARRERA, NC. and MORETZSOHN, F., 2010. Encyclopedia of Texas Seashells: Identification, Ecology, Distribution, and History. Texas: Texas A\&M University Press. 512 p.

WEISBOARD, NE., 1962. Late Cenozoic gastropods from Northern Venezuela. Bulletins of American Paleontology, vol. 42, no. 193, p. 1-734.

WERNER, EE. and HALL, DJ., 1977. Competition and habitat shift in two sunfishes (Centrarchidae). Ecology, vol. 58, no. 4, p. $869-876$. http://dx.doi.org/10.2307/1936222. 